\title{
An Introduction to Legislation in Jewish Law, with References to the American Legal System
}

Samuel J. Levine

Touro Law Center, slevine@tourolaw.edu

\section{Recommended Citation}

29 Seton Hall L. Rev. 916 (1998-1999)

This Article is brought to you for free and open access by the Faculty Scholarship at Digital Commons @ Touro Law Center. It has been accepted for inclusion in Scholarly Works by an authorized administrator of Digital Commons @ Touro Law Center. For more information, please contact Iross@tourolaw.edu. 


\title{
An Introduction to Legislation in Jewish Law, with References to the American Legal System
}

\author{
Samuel J. Levine*
}

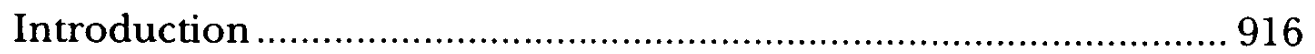

I. Categories of Legislation .................................................. 918

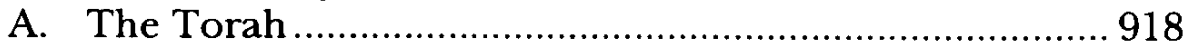

B. Rabbinic Legislation ..................................................... 920

1. Positive Legislation ...................................................920

2. Negative Legislation.................................................... 922

a. Meat and Milk .................................................... 922

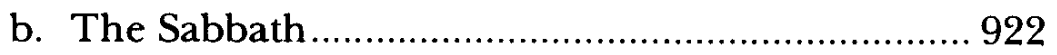

II. Scope of Rabbinic Legislation: License and Limitations ...... 925

A. Sources of Authority .................................................... 925

B. Limitations on Legislative Authority ............................... 927

1. "You shall not add" ................................................. 927

2. "You shall not take away" ........................................... 929

3. Communal Role in Legislation ................................. 931

III. Legislation Over Time: Changed Circumstances .................. 932

A. Biblical Legislation ........................................................... 932

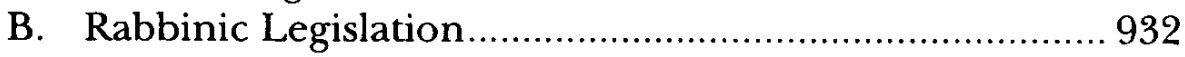

1. General Principles ................................................. 932

2. Suspension of Rabbinic Legislation Without Further Legislative Action: Fringes on Four-Cornered Linen Garments ....................................................... 934

Conclusion 935

\section{INTRODUCTION}

The separation of powers among different branches of government stands as one of the fundamental institutions of the American legal system. The Constitution vests in Congress "[a]ll legislative

- Assistant Legal Writing Professor \& Lecturer in Jewish Law, St. John's University School of Law. B.A., Yeshiva University, 1990; J.D., Fordham University, 1994; Ordination, Yeshiva University, 1996; LL.M., Columbia University, 1996. I thank Steven Friedell, Rabbi David Pahmer, Sheldon Nahmod, and Irene Rosenberg for helpful comments and encouragement, and Fraida Liba for inspiration. 
Powers," in the President " $[t]$ he executive Power," and in federal courts " $[t]$ he judicial Power." Indeed, in the past term, in Boerne v. Flores, ${ }^{4}$ the United States Supreme Court affirmed the vital nature of the separation of powers by striking down as a violation of this doctrine the Religious Freedom Restoration Act. ${ }^{5}$

Nevertheless, it would be inaccurate to suggest that courts do not serve a legislative function. In addition to the central role of courts in the legislative process through interpreting statutes and through the power of judicial review, ${ }^{6}$ it is not uncommon for judges to legislate from the bench. The prominent and influential judge and legal thinker, former Supreme Court Justice Benjamin N. Cardozo, acknowledged the phenomenon of judicial legislation. ${ }^{7}$ It is somewhat ironic that the same Court term that produced the Boerne decision, emphasizing the exclusive power of the courts to adjudicate the law, saw the emergence of what New York Times reporter Linda Greenhouse has called "a striking amount of ... judicial legislating." In fact, according to Greenhouse, even those who publicly decry judicial legislating have come to view it as part of a "tacitly understood and widely accepted reality."

This Article primarily examines the roles of legislative and judicial bodies, in the context of a discussion of broader principles of legislation in the Jewish legal system. In recent years, American legal scholars have increasingly looked to Jewish law as a model of an alternative legal system that considers many of the issues present in the American legal system. ${ }^{10}$ In relation to the roles of legislative and ju-

I.S. CONST. art. I, $\S 1$.

2 U.S. CONST. art. II, $\S 1$, cl. 1 .

3 U.S. CONST. art. III, $\$ 1$.

117 S. Ct. 2157, 2172 (1997).

5 The Religious Freedom Restoration Act, 42 U.S.C. $\$ 2000 \mathrm{bb}$ (1993), was enacted by Congress in response the Supreme Court's decision in Employment Division v. Smith, 494 U.S. 872 (1990).

'See Marbury v. Madison, 5 U.S. (1 Cranch) 137, 177 (1803).

7 See, e.g., Benjamin N. Cardozo, The Nature of the Judicial Process 113 (1921) ("If you ask me how [the judge] is to know when one interest outweighs another, I can only answer that he must get his knowledge just as the legislator gets it, from experience and study and reflection; in brief, from life itself.") Judge Richard Posner has written that Cardozo thus "appears to license uncanalized judicial discretion." Richard A. Posner, CARdozo: A Study in Reputation 29-30 (1990).

8 Linda Greenhouse, Sure Justices Legislate: They Have To, N.Y. TIMES, July 5, $1998, \S 4$, at 1 .

Id.

10 See, e.g., Samuel J. Levine, Jewish Legal Theory and American Constitutional Theory: Some Comparisons and Contrasts, 24 HASTINGS CONST. L.Q. 441, 442-43 nn.3-11 (1997) [hereinafter Jewish Legal Theory]; Suzanne Last Stone, In Pursuit of the Counter-Text: The Turn to the Jewish Legal Model in Contemporary American Legal Theory, 106 HARV. L. 
dicial bodies, the Jewish legal system provides a particularly illuminating contrast to the American legal system, in part because in Jewish law, the same authority, the Sanhedrin, or High Court, serves in both a legislative and judicial capacity.

Interestingly, though, as a result of the express license for the same authority in Jewish law to serve two separate functions, the two functions are rather clearly delineated, each bounded by specific rules and regulations. Thus, an analysis of the legislative function of the Sanhedrin may shed light on an analysis of the proper legislative function of American courts. A secondary aim of this Article is to illustrate some of the conceptual foundations and functionings of the Jewish legal system evident in the various substantive areas of legislation examined, relying in part on the work of contemporary scholars of Jewish law, again in the hope that the analysis might illuminate conceptual areas of American legal thought.

Part I of the Article describes the different categories of legislation in Jewish law, exploring the distinction between divine legislation, found in the Torah, and rabbinic legislation, enacted by human authorities. Part II discusses the sources for and scope of rabbinic legislative authority. Part III of the Article examines the issue of interpreting legislation over time, when circumstances may have changed since the enactment of the legislation. The Article concludes with the hope that this project, building on the increased interest in Jewish law among American legal scholars, will further demonstrate the relevance of Jewish law to the study of American law.

\section{CATEGORIES OF LEGISLATION}

\section{A. The Torah}

Professor Menachem Elon has aptly described the "one basic norm and one single supreme value" in Jewish law: "the command of God as embodied in the Torah given to Moses at Sinai." In his

REV. 813, 817-19 nn.14-28 (1993).

" Menachem Elon, Jewish Law: History, Sources, Principles 233 (Bernard Auerbach \& Melvin J. Sykes trans., 1994) [hereinafter JEWISH LAW]. A number of works in English provide a general introduction to the history, structure, and methodology of the Jewish legal system. See generally, e.g., IrVing A. BREITOWitz, BetweEn Civil Law and Religious Law: The Plight of the Agunah in American Society 307 13 (1993); ELON, JEWISH LAW, supra, at 228-39, 281-399; Menachem Elon, The Legal System of Jewish Law, 17 N.Y.U. J. INT'L L. \& POL. 221 (1985); DAVID M. FELDMAN, Birth Control. in Jewish Law: Marital Relations, Contraception and Abortion 318 (1968); Aaron Kirschenbaum, EQuity in Jewish Law: Halakhic Perspectives in LAW: FORMALISM AND FLEXIBILITY IN JEWISH Civil LAW 289-304 (1991); NAHUM RAKOVER, A GuIDE TO THE SOURCES OF JeWISH LAW (1994); Levine, Jewish Legal Theory, 
Code of Law, the Medieval scholar Maimonides explains that the commandments in the Torah are eternally binding and not subject to abrogation. ${ }^{12}$ Indeed, in his discussion of thirteen fundamental principles of Judaism, Maimonides repeatedly emphasizes the immutable authority of the laws in the Five Books of Moses. ${ }^{13}$ Therefore, in categorizing legislation in Jewish law, Professor Elon has observed that the Torah is "the supreme legislation of the Jewish legal system. It is the written 'constitution' of Jewish law, having its ultimate source in divine revelation .... [A]ll legislation promulgated after the revelation of the supreme legislation has been subordinate."14

Though divine in origin, the Torah requires human interpretation to be understood and applied as a legal text. To facilitate such interpretation, God revealed to Moses at Sinai, together with the Written Torah, an Oral Torah, ${ }^{15}$ consisting of revealed interpretations of certain laws as well as hermeneutic rules to be used by legal authorities to derive further interpretations. ${ }^{16}$ Both the written text of the Torah and the interpretations carry the authority of supreme legislation, incorporated in the term d'oraita, a Talmudic adjective form of the Aramaic translation of "Torah." Unlike the revealed text and interpretations, however, laws derived through human interpretation are subject to dispute and reversal by later legal authorities. ${ }^{18}$ In fact, one of the principal functions of the Sanhedrin in each generation was to serve as the ultimate arbiter of the law through its own interpretation of the Torah. ${ }^{19}$

supra note 10 .

12 See Maimonides, Mishne TORAH [hereinafter, Maimonides, Code of Law], Laws of Yesodei Ha-Torah 9:1 (citing Leviticus 23:14; Deuteronomy 13:1, 29:28, 30:12); Laws of Mamrim 2:9.

13 See Maimonides, Introduction to Perek Chelek, in INTRODUCTIONS TO COMMENTARY ON THE MISHNA 107, 139-47 (Mordechai Rabinowitz, ed., 1961) [hereinafter Perek Chelek].

14 ELON, JEWISH LAw, supra note 11, at 479, 481.

15. See Levine, Jewish Legal Theory, supra note 10, at 445.

16 For a discussion of the different sources and methods of interpretation in Jewish law, see id. at 447-51.

17 See Nachmanides, Commentary to Maimonides, BoOK of Commandments, commentary to Chapter 2.

is See MaImonides, Code of LAW, supra note 12, Laws of Mamrim 2:1; Levine, Jewish Legal Theory, supra note 10, at 468-77.

19 See MaImonides, CODE of Law, supra note 12, Laws of Mamrim 1:1-1:2, 2:1. Thus, as I have suggested elsewhere, interpretation of the Torah parallels interpretation of the United States Constitution by the Supreme Court, which has the authority and duty to determine the meaning of the Constitution. See Levine, Jewish Legal Theory, supra note 10, at $446 \&$ n. 26. 


\section{B. Rabbinic Legislation}

Although the laws in the Torah can be described as "legislation," because those laws are divinely mandated and therefore not subject to legislative modification, an analysis of legislative principles in Jewish law might instead focus on rabbinic legislation. ${ }^{20}$ Aside from its adjudicatory function, the Sanhedrin served in a legislative capacity. Legislation enacted by the Sanhedrin, subordinate to the legislation in the Torah, is termed d'rabbanan, from the Aramaic for "rabbinic."."

Like the laws of the Torah, which consist of both positive commandments and negative commandments, rabbinic legislation can also take both positive and negative form. In addition, although all negative legislation in a sense serves to safeguard adherence to the laws in the Torah, conceptually negative rabbinic legislation can be further divided into sub-categories of legislation, relating to both the purpose and the parameters of the legislation.

\section{Positive Legislation}

As Maimonides explains in his Introduction to the Mishna, ${ }^{22}$ one category of rabbinic legislation is takanot, or positive legislation,

${ }^{20}$ See ELON, JEWISH LAW, supra note 11, at 480-81, noting that

[t]he substance of the supreme legislation is fixed, perpetual, and beyond change .... Thus, when we speak of legislation as one of the legal sources of Jewish law (i.e., a source recognized in the Jewish legal system itself as an instrument for continued [legal] creativity and development), we refer, of course, to legislation by [legal] authorities and other competent legislators. Although such legislation is subordinate legislation, we refer to it, for convenience and brevity, simply as "legislation."

Id. In a roughly similar manner, the United States Constitution was enacted through a legislative act, but retains the status of supreme legislation, binding on and setting boundaries for all subordinate legislation. Of course, the Constitution differs from the Torah in that it is subject to amendment, though the process and concept of constitutional amendment present numerous complex practical and theoretical issues. See generally, Responding to Imperfection: THE THEORY and Practice of CONSTITUTIONAL AMENDMENT (Sanford Levinson ed., 1995).

${ }^{21}$ Historically, there existed a functioning Sanhedrin from the time of Moses through the fourth century C.E. See ARYEH KaPLAN, THE HANDBOOK OF JEWISH THOUGHT 209 (1979). After the Sanhedrin was disbanded, there remained for many centuries central legal authorities that continued to adjudicate the law and enact legislation, though these courts did not have the status of a Sanhedrin. See id. at 23638. In later times, in the absence of a central authority, local courts carried the authority to adjudicate and enact local laws. See ELON, JEWISH LAw, supra note 11, at 486-89, 666-75. For the purposes of analyzing legal and conceptual issues in legislation in Jewish law, this Article focuses on the Sanhedrin, which functioned in the full capacity of a central, authoritative adjudicatory and legislative body.

${ }_{22}$ The Mishna, which was compiled in the Land of Israel around the year 188 C.E., documented and codified the Oral Torah. The Mishna serves as the basis for the further development of the Oral Law in the Gemara, which was redacted in 
which includes both laws implemented for a clearly religious or ritual purpose and laws implemented to improve the nature of interpersonal dealings. ${ }^{23}$ Because these laws were enacted by the same legal authorities who functioned as arbiters of the laws of the Torah, these authorities were careful to distinguish rabbinic legislation from divine legislation or from interpretations of divine legislation. ${ }^{24}$ The most poignant illustration of these distinctions may be the variety of functions that Moses served after the Revelation at Sinai. In listing some examples of positive legislation, Maimonides includes legislation enacted by Moses. ${ }^{25}$ Thus, Moses played at least three different and distinct roles in the legal system. First, he transmitted the revealed Written and Oral Torah. Second, he served as a judge and an interpreter of those areas of the law that required interpretation. Finally, he served as a legislator of rabbinic law. Although Moses was unique in the first of these roles, ${ }^{26}$ his functioning as both a judge and a legislator provides an analogue for the dual function of the Sanhedrin.

Perhaps the most widely known example of positive rabbinic legislation is the obligation to light the menorah on Chanuka. This legislation was enacted to commemorate the miraculous events of the Nation of Israel's military victory over the Syrian-Greeks and the subsequent burning of a small amount of oil in the Temple menorah that lasted for eight days. ${ }^{27}$ Although the practice of lighting the menorah in the Temple had been divinely mandated, ${ }^{28}$ there was no such obligation incumbent upon individuals prior to the events of Chanuka. As these events occurred more than one thousand years after the Revelation at Sinai, it was the legal authorities living at the time of the miracles who enacted rabbinic legislation requiring individuals to light the menorah on Chanuka.

Babylonia around the year 589 C.E. Together, the Mishna and the Gemara comprise the Talmud. See Levine, Jewish Legal Theory, supra note 10, at 445 n. 17.

${ }_{29}$ See Maimonides, Introduction to the Mishna, in INTRODUCTIONS TO COMMENTARY ON THE MiSHNA 41-42 (Mordechai Rabinowitz, ed., 1961) [hereinafter Introduction to the Mishna].

${ }_{24}$ See infra Part II.B.1.

25 See Maimonides, Introduction to the Mishna, supra note 23, at 41.

${ }^{26}$ See Maimonides, Perek Chelek, supra note 13, at 140-46 (describing the unique nature and status of Moses' prophecy).

${ }_{27}$ See MAImONIDES, CODE OF LAW, supra note 12, Laws of Chanuka, 3:1-3:2.

${ }^{28}$ See Numbers 8:1-4. 
2. Negative Legislation

a. Meat and Milk

The other category of rabbinic legislation that Maimonides lists is gezeirot, negative legislation. ${ }^{29}$ This legislation was enacted in order to safeguard many of the laws of the Torah by adding a protective "fence" around those laws. ${ }^{30}$ For example, in three separate places, the Torah prohibits cooking a kid in its mother's milk." Through expansive interpretation of these verses, the Talmud understands this prohibition to include not only cooking meat and milk together, but also eating and deriving benefit from meat and milk that are cooked together. ${ }^{32}$ At the same time, the Talmud employs hermeneutic principles to limit the prohibition to the meat of certain animals that are similar to goats, excluding other meat such as poultry. ${ }^{33}$ Yet, the Talmud adds that rabbinic legislation was enacted prohibiting eating any meat together with milk. ${ }^{34}$ This legislation was based on the concern that people would not distinguish between different kinds of meat, and therefore, if permitted to eat poultry and milk together, would believe that they were likewise permitted to eat all meats together with milk. ${ }^{95}$ Thus, to protect against a violation of the laws in the Torah, the legal authorities enacted broader subordinate legislation that would help insure adherence to supreme legislation.

b. The Sabbath

A particularly illuminating example of negative rabbinic legislation is found in the various forms of legislation enacted relating to the Sabbath. The Torah prohibits engaging in melakha ${ }^{36}$ on the Sabbath. ${ }^{37}$ Interpreting the term melakha, the Talmud delineates numerous activities that are prohibited on the Sabbath. ${ }^{38}$ These prohibi-

${ }^{29}$ See Maimonides, Introduction to the Mishna, supra note 23, at 40-41.

${ }^{30}$ See id:; see also infra Part II.A.

31 See Exodus 23:19, 34:26; Deuteronomy 14:21.

32 See Talmud Bavl, Chulin $115 \mathrm{~b}$.

39 See id. at 113a. For a discussion of the hermeneutic principles, see ELON, JEWISH LAW, supra note 11, at 281-399; Bernard Rosensweig, The Hermeneutic Principles and Their Application, 13 TRADITION 49 (Summer 1972).

34 See TAlmud BAVLI, Chulin 103a-104b, 113a.

35 See MAIMONIDES, CODE OF LAW, supra note 12, Laws of Dietary Restrictions 9:4; Maimonides, Introduction to the Mishna, supra note 23, at 40.

36 This term is often translated as "work," see, e.g., THE HOLY SCRIPTURES 173 (Jewish Publication Society 1955), but denotes a broad range of generally creative activity prohibited on the Sabbath.

37 See, e.g., Exodus 20:10.

s8 See Talmud BaVl, Shabbath 73a. 
tions have the status of supreme legislation because they are the result of authoritative judicial interpretation of the Torah. In addition to interpreting the Biblical prohibitions, legal authorities enacted negative rabbinic legislation prohibiting other activities in order to safeguard the observance of the Sabbath. ${ }^{39}$ According to Maimonides, some of these activities were prohibited because they are similar to activities that are Biblically prohibited, while others, though not inherently similar to Biblical prohibitions, were prohibited out of a concern that such conduct might nevertheless lead to the violation of Biblical prohibitions. ${ }^{40}$ Finally, Maimonides lists a third category of rabbinic legislation intended to preserve the unique qualities of the Sabbath by prohibiting conduct not conducive to the spiritual nature of the day. ${ }^{41}$

The laws involving the institution of mukza illustrate some of the concerns that serve as a basis for these categories. The Talmud relates that among the activities that were rabbinically prohibited on the Sabbath was the moving of objects that had no purpose on the Sabbath. The Talmud describes a structure of rabbinic legislation that classified various objects as mukza, or set aside from use on the Sabbath, either because they had no intrinsic purpose on the Sabbath or because they were specifically set aside not to be used. ${ }^{42}$ These objects generally could not be moved on the Sabbath, although the legislation incorporated exceptions that permitted certain types of objects to be moved when a need arose on the Sabbath. For example, writing is among the activities prohibited on the Sabbath; ${ }^{49}$ therefore, it is rabbinically prohibited to move a pen, which has the primary function of being used for a Biblically prohibited activity, and thus generally serves no purpose on the Sabbath. However, because, for purposes other than the Sabbath, a pen functions as an intrinsically useful object, it can be moved if a permitted use for it arises on the Sabbath. ${ }^{44}$

A number of reasons are provided by the Talmud and by Maimonides for the legislation of the institution of mukza, corresponding to some of the general rationales Maimonides offers for rabbinic legislation relating to the Sabbath. The Talmud states that the rabbinic

39 See MAIMONIDEs, CODE OF LAW, supra note 12, Laws of the Sabbath, ch. 21-28.

40 See id. at 28:1.

${ }^{41}$ See id. at 24:1 (citing Talmud Bavl, Shabbath 113a-b, 150a).

42 See TAlmud Bavl, Shabbath; MAImONIDES, CODE Of LAW, supra note 12, Laws of the Sabbath 24:12-26:23.

43 See TAlMUd BAVL, Shabbath 73a.

44 See id. at 124a-b; MAIMONIDES, CODE OF LAW, supra note 12, Laws of the Sabbath 25:3. 
prohibition against moving objects that are mukza was enacted as a safeguard against a Biblical law prohibiting carrying objects between private and public domains. By limiting the class of objects permitted to be moved to those which were necessary on the Sabbath, the legislation aimed to decrease the possibility that objects would be improperly carried from a private domain to a public domain. ${ }^{45}$ Maimonides suggests that the laws of mukza serve to safeguard many other Biblical prohibitions as well. For example, in preventing the moving of objects that have a primary use for activities prohibited on the Sabbath, the laws decrease the chances that such activities will be performed. ${ }^{46}$ Finally, Maimonides adds a third reason for the laws of mukza, explaining that refraining from moving objects that are ordinarily moved on a weekday will highlight the unique spiritual nature of the Sabbath. ${ }^{47}$

Contemporary scholars of Jewish law have likewise distinguished categories of rabbinic legislation relating to the Sabbath and have noted the legal significance of such classifications. An illustration of the legal ramifications that emerge from these classifications involves the case of a minor illness on the Sabbath. With the exception of murder, idolatry, and certain forms of illicit sexual relations, all of the laws in the Torah may and must be violated when necessary to save a life. ${ }^{48}$ Thus, if necessary, the laws of the Sabbath are suspended in the face of a life-threatening illness. ${ }^{49}$

However, when there is a minor illness that poses no possible threat to human life, Biblical prohibitions remain intact, and only some forms of rabbinic legislation are suspended. Rabbi Hershel Schachter has observed that the examples of such legislation, provided by the Talmud and later legal authorities, fall under the category of laws enacted not because of an intrinsic similarity to Biblical prohibitions, but out of a concern that permitting certain activities might nevertheless lead to the violation of Biblical laws. In contrast, rabbinic legislation that was enacted as an independent prohibition

45 See TAlmud Bavl, Shabbath 123a-24b; RA'AVAD, CommentaRY to MaImonides, MiShNE TORAH, Laws of the Sabbath 24:12. The parameters of the Biblical prohibition are complex and were supplemented by various forms of rabbinic legislation. See MAIMONIDES, CODE OF LAW, supra note 12, at 12:8-19:26.

46 See MAIMONIDES, CODE OF LAW, supra note 12, at 24:13.

47 See id. at 24:12-13.

48 See id., Laws of Yesodei Ha-Torah 5:1-2.

49 See id., Laws of the Sabbath 2:1. Indeed, Maimonides describes at length the imperative to violate the Sabbath even when there is only a possibility of danger to human life. See id. at ch. 2. 
because of a similarity to a Biblical prohibition remains in effect when there is a minor illness. ${ }^{50}$

\section{SCOPE OF RABBINIC LEGISLATION: LICENSE AND LIMITATIONS}

Because the Written Torah serves as the supreme and constitutional legislation in Jewish law, rabbinic license to enact additional subordinate legislation must find its source in the Written Torah. Additionally, the scope of rabbinic authority in enacting legislation is subject to limitations, based in the Torah, which serve as a checking device to the discretion of rabbinic legislators.

\section{A. Sources of Authority}

In its discussion of the rabbinic command to light the menorah on Chanuka, the Talmud notes that, similar to the observance of Biblical commandments, observance of the lighting of the menorah is preceded by the recitation of a blessing acknowledging God's com-

50 See Hershel Schachter, Eretz Hatzevi 50-51 (1992). Rabbi Schachter dedicates a chapter of this book to illustrations of many other legal ramifications that emerge from the distinction between these categories of legislation. See id. at 50-61; see also infra note 69. Rabbi Schachter also observes that, in addition to legislation relating to the Sabbath, the distinction has applications to numerous other areas of law. See SCHACHTER, supra, at 51-52, 60.

Another contemporary scholar, Rabbi Yitzchak Adler, has observed similar distinctions in various areas of the law. Rabbi Adler refers to "secondary legal rules which are intended to enlarge the scope of the base law beyond its original parameters." See YitzchaK AdLer, Lomdus: A SUbSTRUCtURAL ANAlysis 1 (English section) (1989). Rabbi Adler refers to such a secondary rule as an "expansionary vehicle" and distinguishes between "extensions of the parent statute" and expansions which "may be perceived as newly created, independent and external such that the secondary prohibitions and obligations are not actual extensions of the base law." Id. at 12. According to Rabbi Adler, "extensions" will share the characteristics and properties of the base law more closely than will "creations." See id.

Rabbi Adler applies this framework to many laws, including rabbinic legislation relating to the Sabbath. Rabbi Adler's observations in this area mirror those of Rabbi Schachter. In Rabbi Adler's terminology, rabbinic legislation enacted as a "creation" is suspended in the case of a minor illness, while legislation enacted as an "extension" remains intact, more closely approximating the base law of Biblical prohibitions that are suspended only when a life is in danger. See id. at 11-12 (Hebrew section).

In a sense, it would seem that rabbinic legislation, subordinate to the base laws of the Torah, is a prime example of such "expansions." Indeed, Rabbi Adler applies his framework to various areas of rabbinic legislation. See id. at 10-14. It is interesting, then, that Rabbi Adler also applies his analysis to Biblical laws. Although the laws within the Torah cannot be distinguished as "supreme" or "subordinate," conceptually some of the laws can be understood as expansions of other laws. See id. at 1-10. 
mand..$^{51}$ The text of the blessing includes the statement that God "commanded us to kindle the Chanuka lights."

The Talmud suggests two possible sources to support the notion that lighting the menorah, though rabbinically legislated, is in another sense divinely mandated. The first source, on which Maimonides relies in his Code of Law, is the Biblical description of rabbinic judicial authority, stating that:

When there is a matter of law that you are unable to decide ... you shall go up to the place that God will choose. And you shall approach the ... judge[s] who will be in those days and you shall inquire, and they will you tell you the law. And you shall act according to that which they will tell you ... and you will observe all that which they will teach you. According to [that] which they will tell you, you shall act; do not veer from that which they tell you, to the right or to the left. ${ }^{53}$

The Talmud understands this passage, carrying the warning not to veer from the judge's teachings, to authorize not only rabbinic adjudication but rabbinic legislation as well. ${ }^{54}$ Thus, as Maimonides explains, although the lighting of the menorah is in fact an example of subordinate rabbinic legislation, the blessing recited before lighting the menorah acknowledges the divine command to observe rabbinic legislation. $^{55}$

Similarly, the Talmud identifies a Biblical source for the authority of negative rabbinic legislation, such as the protective measures implemented to prevent violation of the Biblical laws of the Sabbath or Biblical prohibitions against eating meat and milk together. The Talmud interprets the language of the Biblical verse "You shall keep My charge" as a mandate for legal authorities to enact safeguards to Biblical prohibitions. ${ }^{57}$

51 See Talmud Bavli, Shabbath 21 b.

52 Id.

53 Deuteronomy 17:8-11.

54 See also MAIMONIDES, CODE OF LAW, supra note 12, Introduction. Some scholars suggest that this verse is also necessary to explain why the enactment of positive rabbinic legislation, such as lighting the Chanuka menorah, does not violate the Biblical prohibition not to add to the divine law. See Hershel SCHACHTER, B'IKVEI Hatzoan 110 (1997); see also infra Part II.B.1.

${ }^{55}$ See MAIMONIDES, CODE OF LAW, supra note 12, Laws of Blessings 11:3. The same principle is supported by the Talmud's second source for the authority of rabbinic legislation, the Biblical verse "[a]sk your father and he will inform you, your elders and they will tell you." Deuteronomy 32:7.

${ }^{56}$ Leviticus 18:30. The Hebrew words used in this verse for both "keep" and "charge" are derived from the root meaning "guard" or "protect."

${ }^{57}$ See TALMUd BAVLI, Yevamoth 2la; see also MAIMONIDES, CODE OF LAW, supra note 12, Introduction; Maimonides, Introduction to the Mishna, supra note 23, at 40. 


\section{B. Limitations on Legislative Authority}

1. "You shall not add"

The Torah commands, "Every matter which I command to you, you shall take care to observe it; you shall not add to it and you shall not take away from it." ${ }^{, 58}$ Although this verse apparently places broad limitations on any subordinate legislation, the precise parameters of the verse are subject to interpretation, as developed in both the revealed and derived Oral Torah. ${ }^{59}$ In particular, it seems clear that the verse cannot preclude all forms of subordinate legislation, in light of other verses in the Torah that license both positive and negative rabbinic legislation. ${ }^{60}$ Maimonides explains that the verse specifically prohibits adding to the Torah per se, in the sense of enacting subordinate laws in a form that suggests supreme authority. ${ }^{61}$ For example, to protect against the violation of the Biblical prohibition on eating certain forms of meat cooked with milk, legal authorities are authorized to prohibit eating poultry and milk together as well if they explain that the legislation is a rabbinic decree designed to safeguard the Biblical law. ${ }^{62}$ They are precluded, however, from enacting such legislation and stating that poultry is included in the category of meat in the Biblical prohibition. ${ }^{63}$

58 Deuteronomy 13:1.

59 See supra Part I.A. In a sense, the necessity to interpret the parameters of the broad command "you shall not add to it" parallels the need to interpret broad dictates in the United States Constitution, such as "Congress shall make no law . . .." U.S. CONST. amend. I.

60 See supra Part II.A. Similarly, the interpretation of any segment of a statutory code must integrate an understanding of the structure of the entire statutory scheme. Again, the United States Constitution presents a particularly useful parallel, as each section of the Constitution, often containing broad language, must be interpreted in conjunction with both the text and interpretations of other sections. See generally, e.g., CHARLES L. BlaCK, JR., STRUCTURE AND RELATIONSHIP IN CONSTITUTIONAL LAW (1969).

61 See Maimonides, COdE Of LAW, supra note 12, Laws of Mamrim 2:9. According to the Talmud, the verse in Deuteronomy 13:1 also prohibits additions to the mode of performance of specific Biblical commandments, such as observing an eighth day to a holiday that lasts seven days. See TAlmud BAVLI, Rosh Hashana 28b; SCHACHTER, B'IKVEI HATZOAN, supra note 54, at 111-12 \& 111 n.3.

62 See supra Part I.B.2.a.

69 See MAIMONIDES, CODE OF LAW, supra note 12, Laws of Mamrim 2:9; see also 2 NaCHManides, CommentaRy ON THE TORAH 360-61 (Chaim Chavel ed., 1960) (commenting on Deuteronomy 4:2). Likewise, in enacting positive legislation, such as the lighting of the menorah on Chanuka, rabbinic authorities were required to describe the legislation as rabbinic in origin and were prohibited from stating that it was a Biblical law. See MAIMONIDES, supra. 
Moreover, the command not to add to the Torah places additional checks on rabbinic legislative discretion, while further emphasizing the distinction between Biblical and rabbinic legislation. The Talmud relates the rule that rabbinic legislation was enacted only if there existed a substantial need for such legislation. ${ }^{64}$ A number of scholars have posited that this rule is derived from the prohibition against adding to the Torah. These scholars explain that the prohibition requires tempering the broad rabbinic legislative authority by limiting it to situations of significant necessity. Legislation in the absence of such need is considered an improper and prohibited addition to the laws of the Torah. ${ }^{65}$

Scholars likewise explain that the Talmudic rule against enacting negative legislation to prevent violation of a previously established rabbinic prohibition ${ }^{66}$ derives from the same principle. These scholars suggest that the requirement of a substantial need for the enactment of rabbinic legislation precludes such legislation in the absence of a danger of violation of Biblical law. The possibility of the violation of a rabbinic prohibition does not qualify as a need sufficiently substantial to allow for further rabbinic legislation. ${ }^{67}$

Nevertheless, it is important to distinguish the scenario of rabbinic legislation enacted to prevent violation of previously enacted rabbinic law from a scenario in which two separate rabbinic prohibitions act in concert. For example, scholars of Jewish law addressed the question of whether poultry and milk products that have not been cooked together may be eaten together. The Biblical prohibition against eating meat and milk products together applies only to food cooked together and does not include poultry. ${ }^{68}$

However, to safeguard against eating meat and milk products that were cooked together, rabbinic legislation was enacted prohibiting eating meat and milk products that were not cooked together as well. In addition, to safeguard against eating milk products together with those kinds of meat included in the Biblical prohibition, rabbinic legislation was enacted extending the category of meat products to include poultry. Thus, any prohibition involving poultry and milk that were not cooked together would rely on two rabbinic enactments. Still, scholars explain, the prohibition remains intact because

${ }^{64}$ See, e.g., TALMUd BAVLI, Eruvin 63b; SchaCHTER, ERETZ HATZEVI, supra note 50, at 135.

65 See SCHACHTER, ERETZ HATZEVI, supra note 50, at 135.

60 See Talmud Bavl, Shabbath 11 a.

67 See SCHAChTER, B'IKVEI HATZOAN, supra note 54, at 48; SCHACHTER, ERETZ HATZEVI, supra note 50, at 58-59.

${ }^{68}$ See supra Part I.B.2.a. 
it is premised on two separate rabbinic prohibitions, enacted as a result of two independent concerns, acting in concert with one another. Such a dynamic does not constitute a rabbinic prohibition enacted for the purpose of safeguarding a further rabbinic prohibition. ${ }^{69}$

\section{2. "You shall not take away"}

Like the command "you shall not add"70 to the Torah, the Biblical decree "you shall not take away" appears to place broad restrictions on the scope and authority of subordinate legislation. Moreover, the implication of the verse, prohibiting abrogation of Biblical commandments, is consistent with a number of other verses in the Torah that declare the immutability of Biblical commandments. ${ }^{72}$ Nevertheless, even this principle is subject to limited exceptions that exemplify the extent of the discretion available to rabbinic legislators.

The Talmud states that, when necessary, the Sanhedrin has the authority to enact legislation mandating the passive violation of a positive Biblical commandment. ${ }^{73}$ For example, the Torah commands that on the holiday of Rosh Hashana, it is incumbent on individuals to hear the sound of the shofar, a ram's horn. ${ }^{74}$ Depending on the calendar of a specific year, Rosh Hashana may fall on different days of the week, including the Sabbath. Under Biblical law, the ob-

69 See SCHACHTER, B'IKVEI HATZOAN, supra note 54, at 48 . Thus, according to most views, separate rabbinic prohibitions can work in concert on the condition that one prohibition was not enacted to safeguard against violation of the other. Notably, though, some scholars have attributed to one Talmudic authority the view that, under certain circumstances, independent rabbinic prohibitions cannot be enforced together. This approach is particularly relevant in relation to negative rabbinic legislation involving observance of the Sabbath, as such legislation can be divided into different categories. See supra Part 1.B.2.b \& note 50.

Scholars suggest that, according to one opinion in the Talmud, see TALMUD BAVLI, Shabbath 1la-llb, rabbinic prohibitions can work in concert only if at least one of the prohibitions falls under the category of laws enacted as independent rabbinic prohibitions because of a similarity to a Biblical prohibition. Under this view, if both prohibitions fall under the category of laws enacted not because of an intrinsic similarity to a Biblical prohibition, but out of a concern that permitting certain activities might lead to the violation of Biblical laws, then the two prohibitions, even if separate and independent of each other, cannot be enforced together. See SCHACHTER, ERETZ HATZEVI, supra note 50, at 58-59.

${ }^{70}$ Deuteronomy 13:1.

7 Id.

${ }^{72}$ See supra note 12.

73 See Talmud BAVl, Yevamoth 89b-90b.

${ }^{74}$ See Leviticus 23:24, 25:9; Numbers 29:1. 
ligation to sound the shofar on Rosh Hashana applies on both weekdays and the Sabbath. ${ }^{75}$

However, rabbinic authorities were concerned about the possibility that the obligation to hear the sound of the shofar might lead to violation of the Sabbath. Specifically, as the Talmud explains, individuals in possession of a shofar but not adept at sounding the shofar might come to carry the shofar to someone else, who would sound the shofar for them. ${ }^{76}$ Carrying the shofar between public and private domains would constitute a violation of the Sabbath." Therefore, to protect against the active violation of the Sabbath, for years that Rosh Hashana fell on the Sabbath, legal authorities enacted rabbinic legislation mandating passive violation of the positive commandment to sound the shofar. ${ }^{78}$

Scholars have suggested a Biblical source for the rabbinic authority, delineated in the Talmud, to enact legislation involving the passive violation of a Biblical commandment. In the principal passage authorizing rabbinic adjudication and legislation, the Torah states "do not veer from that which they tell you, to the right or to the left." Rabbinic exegesis of this verse understands it to require that the teachings of legal authorities be adhered to "even if it appears they are telling you that your left is your right and your right is your left." ${ }^{80}$ Thus, the verse authorizes a ruling that seems to contradict that which is clearly correct. According to some scholars, the verse serves as the source of authority for rabbinic legislation which, in a sense, might seem incorrect or anomalous because it prevents observance of a Biblical law. ${ }^{81}$

${ }^{75}$ See Talmud Bavli, Rosh Hashana $29 \mathrm{~b}$.

${ }^{70}$ See id.

77 See supra text accompanying note 45.

78 See supra text accompanying note 45.

79 See supra Part II.A.

See SifRI, SHOFTIM 154.

81 See Schachter, ERETZ Hatzevi, supra note 50, at 133 (citing Elchanan WASSERMAN, KunTRUS DIVREI SOFERIM 108-09 (Eliezer Wasserman ed., 4th ed. 1989)).

Scholars of Jewish law have identified two possible ways of conceptualizing the legal effect of rabbinic legislation that requires passive violation of a positive Biblical commandment. See ADLER, supra note 50, at 151 (Hebrew section). In the terminology of Rabbi Yitzchak Adler, the rabbinic legislation can be seen as resulting in the "temporary abolition" of the Biblical law, or, alternatively, as placing the Biblical law "in abeyance." See id. at 44 (English section). The different conceptualizations can help explain the nature of rabbinic authority to enact such legislation. See id. at 151 (Hebrew section). In addition, Rabbi Adler understands a number of other issues in Jewish law by extending to other contexts the framework of viewing a limitation on the applicability of laws as either an abolition or an abeyance. See id. at 15064 (Hebrew section). 
Despite the Talmud's conclusion that rabbinic legislation cannot require the active violation of a positive Biblical commandment, ${ }^{82}$ under unique circumstances the Talmud extends the command to heed the words of rabbinic authorities to include the temporary suspension of a negative Biblical commandment. ${ }^{83}$ The Talmud cites the Biblical example of Elijah, who, to stem the rampant practice of idolatry and return the nation to the proper path, offered a sacrifice on an altar at Mount Carmel, despite a prohibition against bringing a sacrifice outside the Temple in Jerusalem ${ }^{84}$ The Medieval legal scholar Ra'avad explains that the source of authority for the temporary suspension of a negative Biblical commandment is the verse in Psalms stating that when "it is a time to work for God, suspend your Torah." ${ }^{85}$

Based on Talmudic sources such as the Talmudic exegesis of the episode of Elijah on Mount Carmel, Maimonides codifies the principle of rabbinic authority to enact legislation temporarily suspending a Biblical law, when necessary to restore the nation to the proper faith and observance. ${ }^{86}$ Maimonides explains the logic behind such authority through a comparison to the work of a doctor. He writes that, as a doctor may amputate an arm or a leg so that an entire organism may live, similarly, in rare occasions, a court may permit the temporary violation of some commandments in order to safeguard communal observance of the law as a whole. ${ }^{87}$

\section{Communal Role in Legislation}

The Talmud states that rabbinic legislation is legally binding only if is determined that the majority of the nation will be able to abide by the legislation. ${ }^{88}$ Therefore, Maimonides explains, if the court enacts legislation with the erroneous belief that most of the nation can abide by the legislation, but later finds this not to be the case, the legislation is null and void and thus may not be enforced ${ }^{89}$

${ }^{82}$ See Talmud Bavli, Yevamoth 89b-90b.

89 See id. at 90b.

84 See id.; Rashi, Commentary ON the Talmud (citing 1 Kings 18 ).

85 RA'AVAD, supra note 45, Laws of Mamrim 2:9 (citing Psalms 119:126).

86 See MAIMONIDES, CODE OF LAW, supra note 12, Laws of Mamrim 2:4.

87 See id. Similarly, the Talmud describes rabbinic authority to enact laws of criminal justice contrary to those delineated in the Torah, when the "needs of the hour" so demand. See Talmud Bavl, Sanhedrin 27a, 46a; Maimonides, CODE Of LaW, supra note 12, Laws of Sanhedrin 24:410.

88 See Talmud Bavl, Avoda Zara 36b-37a.

${ }^{89}$ See MAIMONIDES, CODE OF LAW, supra note 12, Laws of Mamrim 2:6. Moreover, according to Maimonides, if, after enacting legislation, a court erroneously believes that the majority of the nation has abided by the law, a later court that identifies this 


\section{Legislation OVER Time: Changed CirCumstances}

Statutory interpretation plays a central role in American legal practice and scholarship. ${ }^{90}$ One of the vexing questions in statutory interpretation involves the proper way to approach a statute over time when, as a result of changes in circumstances, the rationale for a statute is apparently no longer applicable. ${ }^{91}$ Again, it may be helpful to look at the contrast case of the Jewish legal system, which includes a complex framework for considering the application of legislation when the reason for the legislation no longer applies.

\section{A. Biblical Legislation}

Because of the immutable authority of the laws in the Torah, ${ }^{92}$ Biblical legislation is generally not subject to abrogation or modification. Thus, the Talmud concludes that the commandments in the Torah remain in force even if the apparent rationale for the commandment no longer applies. ${ }^{93}$ However, in the rare event that the Torah provides the reason for a particular commandment, the Talmud concludes that the force of the commandment is dependent on the applicability of its rationale. ${ }^{94}$ Nevertheless, it should be noted that, in practice, the Talmud appears to discourage reliance on even this limited license for restricting the scope of a commandment based on its express rationale. The Talmud does so out of the concern that an individual may be mistaken in believing that the rationale does not apply in a given situation. ${ }^{95}$

\section{B. Rabbinic Legislation}

\section{General Principles}

Unlike the laws of the Torah, rabbinic legislation can be modified by later legal authorities. Such modifications must be consistent

error may nullify the law. See id. at 2:7. For an analysis of these scenarios, see generally Joseph B. Soloveitchik, Shnei Sugei Mesoret, in SHEURIM L'zekHer AbBa MORI (1983).

${ }^{90}$ For a list of some of the scholarship on statutory interpretation, see Richard A. Posner, Legislation and its Interpretation: A Primer, 68 NEB. L. REV. 431, $451-53$ (1989).

${ }^{91}$ See, e.g., RoNALD DWORKIN, LAW's EMPIRE 348-50 (1986).

92. See supra Part I.A.

93 See Talmud Bavl, Sanhedrin 21a. For a description of the Talmudic dispute in this matter, see Levine, Jewish Legal Theory, supra note 10, at 458-61.

94 See Talmud Bavl, Sanhedrin 21a; Levine, Jewish Legal Theory, supra note 10, at 60-61. Compare Frank A. Easterbrook, Statutes' Domains, 50 U. CHI. L. REv. 533, 544 (1983), with Levine, Jewish Legal Theory, supra note 10 at 461 n.111.

95. See Levine, Jewish Legal Theory, supra note 10, at 461. 
with a complex set of rules regulating the discretion of later authorities. ${ }^{96}$ Although these rules apply only to the modification of rabbinic legislation and not to Biblical legislation, they appear to be different from but modeled after the Biblical law, like many areas of rabbinic legislation.

The Talmud states that a Sanhedrin generally cannot abrogate the legislation of an earlier Sanhedrin unless the later Sanhedrin is "greater in wisdom and in number." According to Maimonides, this rule applies even when, as a result of changing circumstances, the reason for the initial legislation no longer exists. ${ }^{98}$ Moreover, Maimonides holds that even this limited license applies only to positive rabbinic legislation. He writes that negative rabbinic legislation, enacted to safeguard Biblical laws, can never be abrogated by later authorities."

Ra'avad, however, argues that, according to the Talmud, the rule that a later court must be greater than the legislating court applies only when the reason for the legislation still applies. Therefore, although rabbinic legislation remains in force even if the reason for a particular law no longer applies, in such a situation, even a court that

96 In this regard, it is important to distinguish the court's legislative function from its judicial or interpretive function. In contrast to the strict regulations on a later court's legislative authority, later courts have broad interpretive discretion. As Maimonides explains, if one court arrives at a legal ruling based on a particular line of reasoning, a later court has the authority and obligation to adjudicate the same issue according to its own reasoning, even if the outcome is different. MAIMONIDES, CODE OF LAW, supra note 12, Laws of Mamrim 2:1.

Nevertheless, if a particular interpretation is codified through legislative action, that interpretation stands as law and, as legislation, ordinarily may not be subject to alteration by later courts serving in an adjudicative capacity. See infra notes 97-100 and accompanying text. This dynamic is again similar to the relationship between courts and legislatures in the American legal system. Although courts have the authority to interpret statutes, if the legislature enacts legislation codifying a particular interpretation of a statute, courts interpreting the statute are then bound by the legislative action.

For a broader discussion of this principle in Jewish law, and its relationship to legal authority and precedent, see generally JOSEPH KARO, KESEF MISHNA; MAIMONIDES, CODE OF LAW, supra note 12, Laws of Mamrim 2: 1; Levine, Jewish Legal Theory, supra note 10, at 468-77; SCHACHTER, ERETZ HATZEVI, supra note 50; Soloveitchik, supra note 89; Elchanan Wasserman, Kuntrus DIVRei Soferim (Eliezer Wasserman ed., 4th ed. 1994).

97 E.g., Talmud BaVli, Eduyoth 1:5. Legal scholars have provided a variety of interpretations for the definition of "wisdom" and "number" in this context. See KAPLAN, supra note 21, at 22425 \& nn.90-91; Samuel J. Levine, Breadth and Boundary: The Powers of Beit Din, HAMEVASER, December 1990, at 4 [hereinafter Levine, Breadth and Boundary].

98 See MAIMONIDES, CODE OF LAw, supra note 12, Laws of Mamrim 2:2.

99 See id. at 2:3. 
is no greater than the legislating court has the authority to repeal the legislation. ${ }^{100}$

2. Suspension of Rabbinic Legislation Without Further Legislative Action: Fringes on Four-Cornered Linen Garments

Notwithstanding the dispute regarding the criteria and mechanics generally necessary for a court to abrogate rabbinic legislation, scholars have suggested that in certain scenarios, rabbinic legislation loses force even without official legislative action. ${ }^{101}$ Rabbi Hershel Schachter has identified a number of laws that apparently fall under this category and are thus patterned after the rule that the applicability of Biblical laws can be limited according to reasons for the laws expressly presented in the Torah. ${ }^{102}$ In addition, these scenarios serve as a further illustration of limitations on rabbinic legislative authority.

For example, the Torah commands the placing of fringes on four-cornered garments. ${ }^{103}$ The Talmud documents that the proper fulfillment of the command requires that some of the fringes be of a particular color and of wool material. ${ }^{104}$ The Talmud also notes that the requirement to affix wool fringes to all garments, including those of linen, is an exception to the Biblical prohibition not to wear a garment composed of a mixture of wool and linen materials. ${ }^{105} \mathrm{Nev}-$ ertheless, despite the propriety of placing wool fringes on a linen garment as an exception to the general rule, Talmudic authorities were concerned that such a practice might, at times, lead to the violation of the Biblical prohibition. ${ }^{106}$ To prevent such a violation, these authorities enacted rabbinic legislation prohibiting placing fringes on linen garments. ${ }^{107}$

According to a number of scholars, however, just as rabbinic legislation must be formulated in such a manner that it will not appear to be Biblical legislation, ${ }^{108}$ rabbinic legislation that suspends a Biblical law must not contradict Biblical law. ${ }^{109}$ Instead, Rabbi Schachter explains, the formulation of such legislation must clearly demon-

See RA'AVAD, supra note 45, Laws of Mamrim 2:2.

See KAPLAN, supra note 21, at 229 \& nn.128-32.

See supra Part III.A; SCHACHTER, ERETZ HaTZEVI, supra note 50, at 135-40.

See Numbers 15:37-40.

See Talmud Bavl, Menachoth 40a.

See id.

See id.

See id.

See supra Part II.B.1.

See SCHACHTER, ERETZ HATZEVI, supra note 50, at 135.
} 
strate the law's status as subordinate legislation enacted for the express purpose of preventing the violation of a particular Biblical law. ${ }^{110}$ Thus, the Talmudic legislators were required to state, as part of the legislation prohibiting fringes on linen garments, that the purpose of the legislation was to protect against the Biblical violation of wearing a garment composed of wool and linen."

In later times, though, as a result of persecution and dispersion of the Jewish nation, the identity of the proper color for the fringes was lost. As a result, the commandment continued to be fulfilled, but without the requirement that some fringes be composed either of the unique color or of wool material. ${ }^{112}$ As wool was no longer required for the fringes, linen became a suitable replacement, and there was no longer a viable concern that placing fringes on linen garments might lead to a violation of the Biblical prohibition. Thus, Rabbi Schachter explains, parallel to Biblical laws, because the express reason for the rabbinic legislation no longer applied, the legislation itself likewise no longer applied. ${ }^{113}$ In this way, Rabbi Schachter explains the suspension of the Talmudic legislation prohibiting placing fringes on linen garments by a Medieval legal authority without the need for further legislative action. ${ }^{114}$

\section{CONCLUSION}

The turn to Jewish law as a contrast case in contemporary American legal scholarship has offered American legal scholars an opportunity to examine concepts important to American law, through the prism of a legal system that shares many conceptual similarities, yet is based in fundamentally different assumptions. Law review pages continue to reflect the growing interest in the Jewish legal system as a contrast case that may shed light on complex and controversial issues in American law. ${ }^{115}$

This study of legislation in Jewish law represents an attempt to build on the increased interest in Jewish law among American legal scholars. Looking at the doctrine of the separation of powers, a legal concept that remains central to American jurisprudence, this Article observes many comparisons and contrasts in the way the two systems

\footnotetext{
110 See id.

111 See id.

112 See id. at 137. See generally RESPONSUM OF ROSH 2:8; Levine, Breadth and Boundary, supra note 97.

113 SCHACHTER, ERETZ HATZEV, supra note 50, at 137.

114 See id.; see also Levine, Breadth and Boundary, supra note 97, at 4, 10.

115 See supra note 10.
} 
approach this doctrine. At the same time, the Article explores a number of both conceptual and substantive areas of Jewish law, through a variety of sources in Jewish legal thought. In particular, the Article introduces the work of contemporary scholars of Jewish law, in an effort to demonstrate the importance of recognizing emerging scholarship when engaging in studies of comparative law and in the hope that this method will spark similar modes of scholarship in the future. 